EESTI NSV TEADUSTE AKADEEMIA TOIMETISED. 31. KOIDE KEEMIA. 1982, NR. 4

ИЗВЕСТИЯ АКАДЕМИИ НАУК ЭСТОНСКОП ССР. ТОМ 31 ХИМИЯ. 1982, 스 4

удК 677.494 .675

В. КИРНЧЕНКО, Л. КУТЬННА, А. ГОИХМАН, В. ПОЛУДЕННАЯ, С. ДЕМЧЕНКО, О. КИРРЕТ, АйлИ КОГЕРМАН

\title{
МОДИФИКАЦИЯ ПОЛИКАПРОАМИДА ЦИКЛИЧЕСКИМИ СИЛАЗАНАМИ
}

V. KIRITSENKO, L. KUTINA, A. GOIHMAN, V. POLUDJONNAJA, S. DEMTSENKO, O. KIRRET, Aili KOGERMAN. POLOKAPROAMIIDI MODIFITSEERIMINE TSOKLILISTE SILASAANIDEGA

V. KIRITCHENKO, L. KUTYINA, A. GOIKHMAN, Y. POLUDYONNAYA, S. DEMCHENKO, O. KIRRET, Aili KOGERMAN. MODIFICATION OF POLYCAPROAMIDE WITH CYCLIC SILASANES

В данной работе сообщается о результатах исследования эффективности модификации поликапроамида (ПКА) путем введения в расплав гексафенилциклотрисилазана. (ГС) в количестве $0,2-1,0$ масс. $\%$ с целью направленното изменения свойств полых полупроницаемых волокон как полимерных мембран наиболее перспективного типа, используемых в процессах разделения газовых смесей, в частности, для выделения аммиака из азото-водородо-аммиачной смеси в цикле синтеза аммиака.

Введение в ПКА ГС в количестве 0,2 масс.\%, как показали измерения газопроницаемости полых волокон из ПКА, приведет к изменению степени проницаемости полимера: коэффициент диффузии аммиака при модификации возрастает от $16,0 \cdot 10^{-8}$ до $58,5 \cdot 10^{-8}\left(\right.$ нсм $\left.^{3} \cdot \mathrm{cm}\right) /$ $/\left(c \mu^{2} \cdot c \cdot a T M\right)$. Коэффициент газопроницаемости полых волокон определяли объемометрическим методом, поверхность полых волокон в ячейке $0,4 \mu^{2}\left[{ }^{1}\right]$. Коэффициенты проницаемости водорода $0,5 \cdot 10^{-8}\left(\right.$ нсм $\left.^{3} \cdot c м\right) /$ $/\left(C M^{2} \cdot c \cdot a T M\right)$ и азота $0,01 \cdot 10^{-8}-0,02 \cdot 10^{-8}\left(\mathrm{HCM}^{3} \cdot C M\right) /\left(C M^{2} \cdot c \cdot a T M\right)$ не обнаруживают заметного изменения при модификации ПКА. Это свидетельствует о том, что введение циклических силазанов в расплав полимера при формовании полых волокон не обусловит возрастания микропористости полимерного материала. Очевидно, в основе модифицирующего действия циклических силазанов лежат процессы структурно-химической модификации, не приводящие к нарушению сплошности материала. С этой точки зрения, представляет интерес изучение влияния добавок ГС на процесс термодеструкции ПКА методами пиролитической газовой хроматографии и DTA. Пиролиз образцов полых волокон из модифицированных ПКА был проведен при температуре $500{ }^{\circ} \mathrm{C}$. Хроматографический анализ продуктов пироли́тического разложения модифицированного ПКА показывает, что введение в расплав ГС не меняет качественного состава продуктов пиролиза волокон из ПКА. На пирограммах не появляется новых компонентов, но имеет место незначительное изменение количества пиролизной воды и аммиака. Эти данные, а -также результаты изучения температуры начала разложения образцов методом ПГХ показывают, что добавка до $1 \%$ ГС заметно не влияет на термостабильность ПКА. Термограммы модифицированного ПКА (рис. 1) были получены на дериватографе системы «ПауликПаулик-Эрдей» при скорости нагревания 6 град/мин. Данные исследования методами DTA и ПГХ согласуются между собой. Однако сле- 


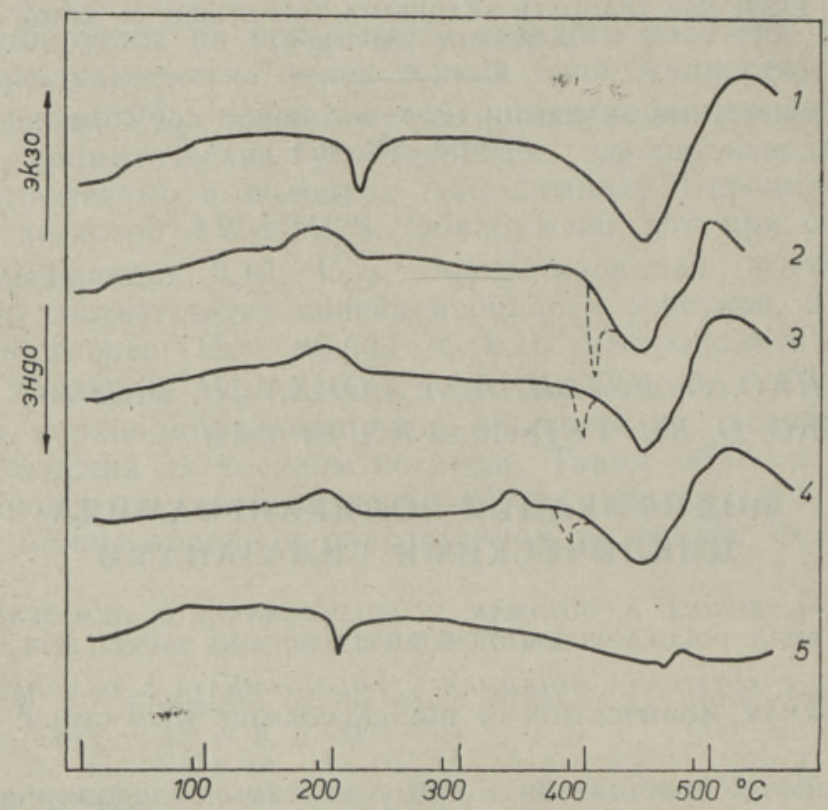

Кривые DTA образцов ПКА, модифицированного гексафенилциклотрисилазаном (ГС). 1 - ПКА; 2 $\Pi K A+0,2$ масс. $\%$ ГС; 3 - ПКА $+0,6$ масc. $\%$ ГС; $4-\Pi К А+1,0$ масс. $\%$ ГС; 5 - ГС.

дует отметить, что у образцов ПКА, содержащих уже до 0,2 масс.\% ГС, при температурах плавления немодифицированного ПКА наблюдается слабый экзотермический эффект, который можно интерпретировать как результат наложения процессов высокотемпературной кристаллизации и плавления образовавшихся кристаллов. Процесс кристал лизации макромолекул ПКА возможен в рассматриваемом случае благодаря ослаблению связей и отщеплению при высоких температурах больших объемных групп атомов, химически связанных с полимерной цепью при низких температурах. Очевидно, кристаллизация проходит здесь в специфических условиях, так как отщепленные молекулы силазана в процессе кристаллизации должны вытесняться на периферию образующихся кристаллов. Это должно привести к замедлению процесса кристаллизации и к образованию термодинамически равновесной полиморфной формы ПКА ( $\alpha$-формы). Рассматриваемый механизм кристаллизации ПКА, модифицированного силазаном, позволяет считать, что на периферии кристаллов ПКА должны существовать области с повышенным содержанием силазана. Учитывая значительную близость молекул силазана к аммиаку, эти области по отношению к нему должны обладать повышенной растворяющей способностью. Поскольку молекулы силазана сконцентрированы в межкристаллитных аморфных прослойках, они повышают эффективность работы аморфной фазы модифицированного ПКА как полимерной мембраны.

\section{ЛИТЕРА Т У Р А}

1. Р ей т ли н г е р С. А. Проницаемость полимерных материалов. М., 1974.

\section{Институт химии \\ Академии наук Эстонской ССР}

